\title{
Empowerment of Microfinance Beneficiaries in India and Bangladesh: A Factor Analysis Approach
}

\author{
Rajib Chakraborty* and R. Vasanthagopal**
}

\begin{abstract}
It is a widely known fact that micro finance plays an important role in empowering the poorer section of the population, particularly rural women, who traditionally lack access to the banking related services. From its basic norm to providing small amount of loan to the poor women to implement a number of social development programmes, micro finance is now considered as a tool of women empowerment. The present paper aims to identify the socio-economic factors that affect the empowerment level of microfinance beneficiaries in India and Bangladesh most. Further, it checks whether demographic characteristics of the beneficiaries have any association with the identified factors.
\end{abstract}

Keywords: Economic empowerment, Microfinance, Social empowerment, Socioeconomic conditions, Factor analysis.

\subsection{Introduction}

Microfinance, an accepted means for empowering poor people, has transformed their living standard, particularly women in the third world nations in an enormous way. By offering small loan to foster small-scale entrepreneurial activities, micro finance brings the financially excluded people in the banking boundary. It offers credit, savings, insurance and other financial services to the underprivileged sections that are too poor to be served by regular banks. From its basic criteria to provide small loan to implement a number of social development programmes, micro finance is now deemed as a tool of empowerment of rural poor, particularly women.

*Research Scholar, Institute of Management in Kerala, University of Kerala, Kerala. (email: keralamphil@gmail.com)

**Assistant Professor, School of Distance Education, University of Kerala, Kerala. (email:vasanthagopalr@yahoo.com) 
According to the United Nations Capital Development Fund (2004), micro finance plays three key roles in development- (i) helps very poor households meet basic needs and protects against risks, (ii) associates with improvements in household economic welfare and (ii) helps empower women by supporting women's economic participation and so promotes gender equity. To bring economic changes and prosperity in the rural family and to popularize the importance of micro credit throughout the world, the United Nations declared 2005 as the "Year of Micro Credit".

Micro finance programmes for the poor have come to occupy a central place in poverty-oriented strategies in Bangladesh. For this, women in Bangladesh have gained an international reputation for their excellent performance as micro finance beneficiaries in micro finance institutions. As a result, in 2006 Grameen Bank, a well renowned micro finance institution and its founder Mohammad Yunus have jointly been awarded Nobel Prize for peace. With financial inclusion emerging as a major policy objective in India, micro finance has occupied centre stage as a promising conduit for extending financial services to unbanked sections of population. From the two micro finance approaches in India, Self Help Group (SHGs) model remains the most widely used model financed by National Bank for Agriculture and Rural development (NABARD). Now SHG model is considered as one of the dominating models in the global micro finance industry.

The present paper aims to pinpoint the factors (based on factor analysis) which largely impinge on the empowerment level of micro finance beneficiaries of Kerala and Chittagong, the two regions in India and Bangladesh, which have been successfully practicing microfinance for empowering the underprivileged poor through financial inclusion. The relationship of demographic characteristics and economic empowerment has also been a subject of analysis at the end of this paper.

\subsection{Review of Literature}

Pitt and Khandker (1998) using data from a special survey carried out in 87 rural Bangladeshi villages during 1991-92, estimated the impact of female and male participants in group-based credit programs. By applying quasi- experimental design of the study, the paper provides separate estimates of the influence of borrowing by men and women or each of the three credit programs (Grameen Bank, BRAC and Bangladesh Rural development Board's RD- 12 program) on household expenditure, no land assets held by women, men's labour supply, women's labour supply, and boys' and girls' schooling. It tells that credit is a significant determinant of many of these outcomes. Furthermore, credit provided to women was more likely to influence these behaviors than credit provided to men. Credit provided women significantly affect all six of the 
behaviors studied at the .05 level of significance whereas credit provided men does so in only one of six cases.

Mahmud (2001) studied data of household survey of 91 villages in 1998 originally undertaken for the evaluation and monitoring of micro-credit programs found the following findings- (a) Participation in NGOs programs had a positive association with women's mobility into more socially acceptable public spheres such as NGO office and health centre, but had little effect on access to the more male dominated public spheres like bank and bazzar; (b) Women in the poor households were more likely to be employed; (c) Household incomes were disaggregated to correspond to male-income (such as sale of crops and field based income) and female income (such as home-based income from poultry). Women were found to have more access in their own income although surprisingly a high proportion of women reported to have access to crop income; (d) Women's decision making role was most common with regard to food expenditures, fairly common to children's schooling and least common to crop production. (e) Participating women in micro-credit programmes were more likely to use contraceptives and to have husbands with a favourable attitude to it compared to nonprogramme participants; (f) Women in relatively better-off households spent less time on the works inside households. Programme participants spend proportionately more time in income earning work regardless of poverty status of households. (g) Access to health care by female and male family members, and the male bias in access to health care, were both lower for non-programme participants; (h) The overall extent of immunization was higher among programme participants.

Hossain (2002) in the study 'Credit for Alleviation of Rural Poverty: The Experience of Grameen Bank in Bangladesh' has mentioned about the in-depth survey over the Grameen Bank beneficiaries of the five project and two control villages. He found that Grameen Bank members had about 50 per cent higher income compared to the target group in the control villages, and about one-fourth higher compared to the target group non-participants in the project village. The positive income effect is mainly due to large increases in income from processing and manufacturing trade and transport services, which Grameen Bank loan finances. The proportion of population living below the absolute poverty line, estimated on the basis of a daily intake of $2150 \mathrm{k}$. cal. and 15 per cent income spent on non-food necessities is estimated at 50 per cent for the project villages compared to the 71 per cent in the control villages. Among the other GB target groups, the poverty stricken population is found at 76 per cent in control villages, 68 per cent among non-participants in project villages and 51 per cent among the GB members.

Raghavan (2009) has revealed that by participating in various income generating and developmental activities, the morale and confidence of women became very high. 
Capacity of the poor women of the State in several areas has gone up considerably. Status of women in families and community has also improved.

A study by Santhosh Kumar and Vasanthagopal (2010) observed that a large number of women micro finance enterprises had been established by the micro finance in Kerala through NHGs, SHGs, group lending models. By creating full time and part time self employment for the poor people, micro finance was proved as a successful method of providing credit to the poor without collateral and creating employments.

Arora and Meenu (2011) made an attempt to understand the role of microfinance in socio economic empowerment of women in the Jalandhar district of Punjab. They observed that microfinance has been effectively contributing to women empowerment significantly to their family development in terms of getting credit for house repairs, education and marriage of their children and also for consumption purpose. The study also found good saving habit among females as maximum number of the respondents were having saving bank accounts (46.9 per cent) and post office savings (18.4per cent).

Angel Anila (2013) revealed that there are indications of positive interventions in the women entrepreneurship process due to the training of EDPs in Tirunelveli district of Tamil Nadu. In this study, the respondents strongly agree that they have gained the optimistic outlook about business, need based innovation production and product formation through EDPs and it is the main reason for the successful business. The optimistic outlook, team work, and risk taking have been major levels of attitudes gained by SHG women entrepreneurs though EDPs.

\subsection{Methodology}

A multi-stage sampling technique has been applied to select the sample. At first the State of Kerala and Chittagong division have been divided into three regions viz. north, central and south. One district from each region representing north, central and south has been selected at random. In the second stage, one panchayat/ branch each has been selected from each district at random. In the last and final stage, 100 beneficiaries each have been selected purposively from each panchayat/ branch. Thus, a total of 600 women micro finance beneficiaries (300 each for Kerala and Chittagong) have been selected as sample for the study.

\subsection{Results and Discussion}

To assess the impact of socio-economic conditions over the level of empowerment of the beneficiaries, Principal Components Analysis (PCA) has been used. 
This approach allows determining which, of a fairly large set of items, hang together as a group, or are answered most similarly by the participants. Before the analysis, Bartler's Test of Sphericity has been applied to test the appropriateness and reliability of the sample size, which found that the sample size is appropriate (Cronbach's alpha value $0.782>0.70)$.

Of the 15 factors considered for the analysis, three factors are extracted with Eigen values greater than 1 which account for 80.44 per cent of the total variance and the remaining 12 factors together account for 19.56 per cent of the total variance (Table 1). The cumulative percentage obtained from Extraction Sums of Squared Loading indicates that the first factor (i.e. ability to buy assets) could make a variation of 47.322 per cent on the empowerment level of beneficiaries. Again, the second and third factors together (i.e. capacity of bearing expense and presence of basic amenities) could make a variation of 33.12 per cent. Further, the first three factors altogether could make a variation of 80.44 per cent.

Table 1: Principal Component Analysis

\begin{tabular}{|c|c|c|c|c|c|c|c|c|c|}
\hline \multirow[b]{2}{*}{ 选 } & \multicolumn{3}{|c|}{ Initial eigen values } & \multicolumn{3}{|c|}{$\begin{array}{c}\text { Extraction sums of } \\
\text { squared loadings }\end{array}$} & \multicolumn{3}{|c|}{$\begin{array}{l}\text { Rotation sums of } \\
\text { squared loadings }\end{array}$} \\
\hline & $\stackrel{\text { డే }}{\varrho}$ & ơ & 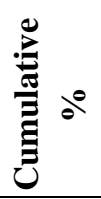 & 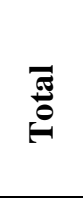 & ¿ & 胥 & $\stackrel{\pi}{\frac{\pi}{0}}$ & 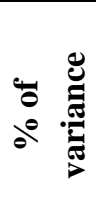 & 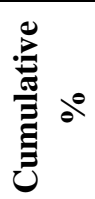 \\
\hline 1 & 7.09 & 47.32 & 47.32 & 7.09 & 47.32 & 47.32 & 5.59 & 37.26 & 37.26 \\
\hline 2 & 3.01 & 20.09 & 67.42 & 3.01 & 20.09 & 67.42 & 3.49 & 23.27 & 60.53 \\
\hline 3 & 1.95 & 13.02 & 80.44 & 1.95 & 13.03 & 80.44 & 2.99 & 19.92 & 80.44 \\
\hline 4 & .851 & 5.671 & 86.12 & & & & & & \\
\hline 5 & .667 & 4.449 & 90.56 & & & & & & \\
\hline 6 & .373 & 2.488 & 93.05 & & & & & & \\
\hline 7 & .300 & 1.999 & 95.05 & & & & & & \\
\hline 8 & .229 & 1.529 & 96.58 & & & & & & \\
\hline 9 & .134 & .892 & 97.47 & & & & & & \\
\hline 10 & .115 & .763 & 98.23 & & & & & & \\
\hline 11 & .090 & .602 & 98.84 & & & & & & \\
\hline 12 & .064 & .424 & 99.26 & & & & & & \\
\hline 13 & .054 & .363 & 99.62 & & & & & & \\
\hline 14 & .035 & .234 & 99.86 & & & & & & \\
\hline 15 & .022 & .144 & 100.0 & & & & & & \\
\hline
\end{tabular}


Figure 1: Scree Plot

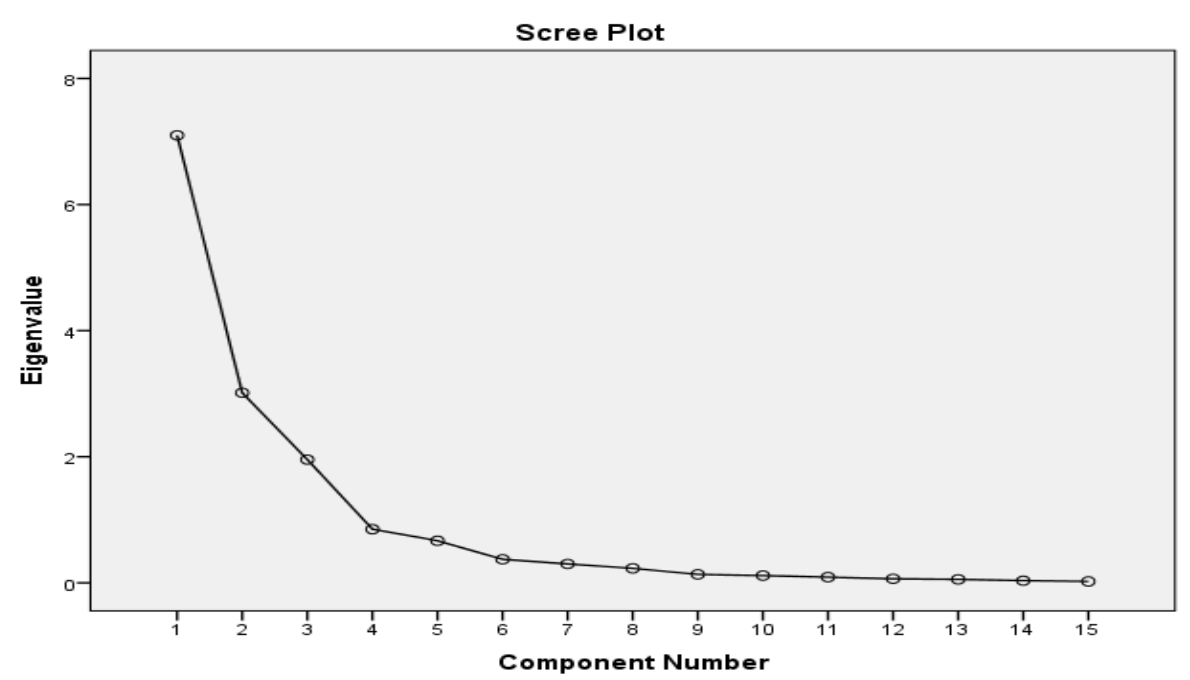

Since the scree plot (Figure 1) begins to flatter beyond component number 3 continuing to component number 15 , it is concluded that there are all together three factors extracted for the purpose of finding most effective factors that affect empowerment.

1. Factor 1 explains a variance of 5.59 which is 37.26 per cent of total variance of 15 variables.

2. Factor 2 explains a variance of 3.49 which is 23.27 per cent of total variance of 15 variables.

3. Factor 3 explains a variance of 2.99 which is 19.92 per cent of total variance of 15 variables.

Table 2 gives the Rotated Component Matrix, which identified three factors from the scale of 15 items. The factors that have been emerged as significant in respect of measuring influence over empowerment level of micro finance beneficiaries are economic empowerment, social empowerment and decision-making power (Table 3).

\subsection{Demographic characteristics and economic empowerment}

To assess the relationship between demographic characteristics (age, income and occupation) and economic empowerment (ability to buy assets), the following fourvariable regression equation has been formulated:

$$
\grave{y}=a+b_{1} x_{1}+b_{2} x_{2}+b_{3} x_{3}
$$

where, $x_{1}=$ age, $x_{2}=$ Income, $x_{3=}$ Occupation and $y=$ Ability to buy assets 
Table 2: Rotated Component Matrix

\begin{tabular}{|l|l|c|c|c|}
\hline \multirow{2}{*}{ Sl.No } & & \multicolumn{3}{c|}{ Component } \\
\cline { 3 - 5 } & & 1 & 2 & 3 \\
\hline 1 & Ability to buy assets & .375 & .113 & .859 \\
\hline 2 & Capacity of bearing expense & .333 & .130 & .856 \\
\hline 3 & Presence of basic amenities & .149 & -.053 & .898 \\
\hline 4 & Recognition in society & .869 & -.013 & .297 \\
\hline 5 & Access to various organization & .874 & .011 & .337 \\
\hline 6 & Ability to solve social issues & .867 & .051 & .247 \\
\hline 7 & Greater involvement in social activities & .894 & .031 & .071 \\
\hline 8 & Power to make large purchase & .828 & .341 & .015 \\
\hline 9 & Taking major decision & .842 & .247 & .073 \\
\hline 10 & Purchase from own earnings & .816 & .195 & .223 \\
\hline 11 & Self-confidence & .367 & .775 & .311 \\
\hline 12 & Mental strength & .099 & .922 & .255 \\
\hline 13 & Sense of future planning & -.026 & .874 & .149 \\
\hline 14 & Type of house & .168 & .581 & -.376 \\
\hline 15 & Nature of family & .102 & .828 & -.249 \\
\hline
\end{tabular}

Extraction Method: Principal Component Analysis.

Rotation Method: Varimax with Kaiser Normalization.

Table 3: Summary of Factor Loadings

\begin{tabular}{|c|l|l|}
\hline Factor No & \multicolumn{1}{|c|}{ Factors } & \multicolumn{1}{c|}{ Specific attributes } \\
\hline 1 & Economic empowerment & $\begin{array}{l}\text { Ability to buy assets } \\
\text { Capacity of bearing expense } \\
\text { Presence of basic amenities in house }\end{array}$ \\
\hline 2 & Social empowerment & $\begin{array}{l}\text { Recognition in society } \\
\text { Access to various organization } \\
\text { Ability to solve social issues } \\
\end{array}$ \\
& & Greater involvement in social activities \\
\hline 3 & Decision making power & $\begin{array}{l}\text { Power to make large purchase } \\
\text { Taking major decision } \\
\text { Purchase from own earnings }\end{array}$ \\
& &
\end{tabular}

Table 4 shows that the multiple correlation coefficient (R), using all the predictors simultaneously, is $0.768\left(R^{2}=0.59\right)$ and the adjusted $R^{2}$ is 0.49 , which means that 48.8 per cent of the variance in economic empowerment (ability to buy assets) can 
62 | MANTHAN: Journal of Commerce and Management, Volume 3, Issue 1

be predicted from age, education and occupation. The ANOVA test (Table 5) also indicates that the combination of the predictors (independent variables) significantly predict economic empowerment (dependent variable) $(\mathrm{p}<.05)$.

Table 4: Multiple Correlation Co-efficient

\begin{tabular}{|c|c|c|c|c|}
\hline Model & R & R square & Adjusted R square & Std. error of the estimate \\
\hline 1 & $.768^{\mathrm{a}}$ & .590 & .488 & .43490 \\
\hline
\end{tabular}

a. Predictors: (Constant), occupation, income, age

Table 5: ANOVA ${ }^{\mathrm{a}}$

\begin{tabular}{|c|l|c|c|c|c|c|}
\hline \multicolumn{2}{|c|}{ Model } & Sum of squares & Df & Mean square & F & Sig. \\
\hline \multirow{3}{*}{1} & Regression & 162.537 & 3 & 54.179 & 286.446 & $.000^{\text {b }}$ \\
\cline { 2 - 7 } & Residual & 112.728 & 596 & .189 & & \\
\cline { 2 - 7 } & Total & 275.265 & 599 & & & \\
\hline
\end{tabular}

a. Dependent Variable: ability to buy assets.

b. Predictors: (Constant), occupation, income, age.

The standardized beta coefficients given in Table 6 shows that that the p-value for beta coefficient of age is .005 , income is .015 , and the same for occupation is .000 , which means that all the three independent variables are significantly contributing to the equation. Hence, it can be deduced that economic empowerment (ability to buy assets) is positively related with age, income and occupation. In addition, the collinearity statistics (given in Table 6) also confirms the contribution of independent variables to the collinearity model as the tolerance value of the three variables is higher than the standardized coefficients.

Table 6: Standadised Beta Coefficients ${ }^{\mathrm{a}}$

\begin{tabular}{|l|c|c|c|c|c|c|c|}
\hline \multirow{2}{*}{ Model } & \multicolumn{2}{|c|}{$\begin{array}{c}\text { Unstandardize } \\
\text { d coefficients }\end{array}$} & $\begin{array}{c}\text { Standardized } \\
\text { coefficients }\end{array}$ & $\mathbf{t}$ & Sig. & \multicolumn{2}{c|}{$\begin{array}{c}\text { Collinearity } \\
\text { statistics }\end{array}$} \\
\cline { 2 - 8 } & $\mathrm{B}$ & $\begin{array}{c}\text { Std. } \\
\text { Error }\end{array}$ & Beta & & & $\begin{array}{c}\text { Tolera } \\
\text { nce }\end{array}$ & VIF \\
\hline (Constant) & .843 & .063 & & 13.468 & .000 & & \\
\hline Age & .130 & .046 & .170 & 2.799 & .005 & .812 & 5.374 \\
\hline Income & .127 & .033 & .205 & 3.833 & .015 & .801 & 4.149 \\
\hline Occupation & .471 & .031 & .516 & 15.224 & .000 & .798 & 1.672 \\
\hline
\end{tabular}

a. Dependent Variable: ability to buy assets 
Further, to test the validity of the assumption that there is no correlation among demographic characteristics and social empowerment, bi-variate correlation coefficient is calculated. The output gives correlation for all pairs of variables and each correlation is produced twice in the matrix (Table 7). The output reveals that the p-values of the correlation coefficient among all demographic variables (except education) and variable of social empowerment for two-tailed test are less than .05 ( $\mathrm{p}<.05)$. From this it can be concluded that there are positive correlation among the variables of demographic characteristics and variables of social empowerment. Results for correlations between other set of variables can also be interpreted similarly. Further, unlike education and social empowerment all others variable are significantly correlated with each other.

Table 7: Correlation (r) of Demographic Characteristics

\begin{tabular}{|c|c|c|c|c|c|c|c|c|c|}
\hline Variables & & $\stackrel{\mathscr{\Xi}}{\mathscr{E}}$ & $\underset{\pi}{80}$ & 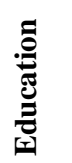 & 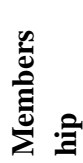 & 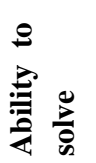 & 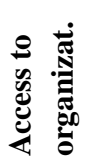 & 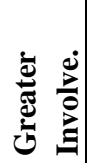 & 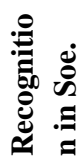 \\
\hline \multirow[t]{2}{*}{ Income } & $\mathrm{r}$ & \multirow[t]{2}{*}{1.00} & .898 & .853 & .789 & .724 & .743 & .803 & .852 \\
\hline & Sig. & & .026 & .055 & .000 & .018 & .000 & .000 & .000 \\
\hline \multirow[t]{2}{*}{ Age } & r & .898 & \multirow[t]{2}{*}{1.00} & .821 & .654 & .725 & .769 & .785 & .623 \\
\hline & Sig & .020 & & .328 & .013 & .004 & .012 & .000 & .014 \\
\hline \multirow[t]{2}{*}{ Education } & $\mathrm{R}$ & .853 & .821 & \multirow[t]{2}{*}{1.00} & .777 & .654 & .673 & .739 & .512 \\
\hline & Sig & .000 & .031 & & .021 & .014 & .000 & .013 & .018 \\
\hline \multirow{2}{*}{$\begin{array}{l}\text { Duration of } \\
\text { membership }\end{array}$} & $\mathrm{r}$ & .663 & .572 & .580 & \multirow[t]{2}{*}{1.00} & .810 & .763 & .533 & .654 \\
\hline & Sig & .005 & .000 & .012 & & .018 & .000 & .000 & .015 \\
\hline \multirow{2}{*}{$\begin{array}{l}\text { Ability to solve social } \\
\text { issues }\end{array}$} & $\mathrm{r}$ & .724 & .745 & .654 & .874 & \multirow[t]{2}{*}{1.00} & .927 & .866 & .724 \\
\hline & Sig & .015 & .044 & .154 & .012 & & .041 & .015 & .000 \\
\hline \multirow{2}{*}{$\begin{array}{l}\text { Access to various } \\
\text { organization }\end{array}$} & $\mathrm{r}$ & .743 & .769 & .673 & .761 & .927 & \multirow[t]{2}{*}{1.00} & .850 & .841 \\
\hline & Sig & .020. & .012 & .055 & .000 & .000 & & .000 & .012 \\
\hline \multirow{2}{*}{$\begin{array}{l}\text { Greater involvement in } \\
\text { community activity }\end{array}$} & $\mathrm{r}$ & .803 & .785 & .739 & .674 & .866 & .850 & \multirow[t]{2}{*}{1.00} & .701 \\
\hline & Sig & .026 & .018 & .231 & .025 & .023 & .012 & & .000 \\
\hline \multirow{2}{*}{$\begin{array}{l}\text { Recognition in the } \\
\text { society }\end{array}$} & $\mathrm{r}$ & .514 & .612 & .586 & .765 & .633 & .510 & .653 & \multirow[t]{2}{*}{1.00} \\
\hline & Sig & .030. & .011 & .241 & .000 & .000 & .011 & .017 & \\
\hline
\end{tabular}

Correlation is significant at the .05 level (2-tailed).

\subsection{Conclusion}

Based on the analysis it is inferred that micro finance has been emerged as a mechanism of eradicating poverty and empowering women beneficiaries. The Grameen bank's joint liability group model of Bangladesh and SHGs-linkage program model of 
India have been considered as the two successful models in the world's micro finance industry. The study further noticed that economic empowerment has made highest impact on the beneficiaries in both the countries after the social empowerment and hence concluded that both the governments of India and Bangladesh have done laudable work towards upgrading women's position in the society through micro finance. So these models can be implemented in other countries too to empower economically downtrodden section of the people, especially women.

\section{References}

Angel Anila, A. (2013). Impact of EDP Curriculum on the SHG Women Entrepreneurship Development. Southern Economist, 52(5): 7-8.

Arora, Sangeeta \& Meenu, (2011). Women Empowerment through Micro Finance Intervention in the Commercial Banks: An Empirical Study in the Rural India with Special Reference to the State of Punjab. Journal of Social Sciences. 2(2): 35-45.

Hossain. M, (2002). Credit for Alleviation of Rural Poverty. The Experience of Grameen Bank in Bangladesh. A Multi- Dimensional Analysis: Outcomes of a BIDS Research Study. Grameen Trust.

Pitt, M. M. \& S. R. Khandker (1998). The Impact of Group-Based Credit Program on Poor Households in Bangladesh: Does the Gender of Participants Matters? Journal of Political Economy, 106(5): 958-996.

Raghavan (2009). A Study of Kudumbashree Projects In Kerala. Journal of Rural Development, 28 (4): $469-484$.

Santhosh kumar, S. \& Vasanthagopal, R. (2010). Micro Credit Dispensation Model and Employment Generation, Southern Economist. 48(17): 9-10.

Simeen Mahmud (2001). Actually How Empowering is Microcredit. Institute of Social Studies, 34(4): 577-605.

United Nations Capital Development Fund (2004). Independent Programme Impact Assessments of the UNCDF Local Development Programmes Mozambique Uganda Mali Cambodia. Main Report. ECIAfrica Consulting (Pty) Ltd. 